\title{
PENGGUNAAN TANAH LIAT SEBAGAI MEDIA PEMBELAJARAN PENGENALAN BENTUK DASAR TIGA DIMENSI BAGI PENDIDIKAN ANAK USIA DINI
}

\author{
Milla Anggamala Supriatna ${ }^{1}$
}

\begin{abstract}
ABSTRAK
Alat permainan yang edukatif dapat digunakan sebagai media dalam proses pembelajaran, sehingga dapat mempertinggi proses belajar dalam pembelajaran yang pada gilirannya diharapkan dapat mempertinggi hasil belajar yang dicapainya. Berbagai penelitian yang dilakukan terhadap penggunaan media dalam pembelajaran sampai pada kesimpulan, bahwa proses dan hasil belajar pada anak menunjukkan perbedaan yang signifikan antara pembelajaran tanpa media dengan pembelajaran menggunakan media yang menarik. Oleh karena itu penggunaan media pembelajaran sangat dianjurkan untuk mempertinggi kualitas pembelajaran. Salah satu media tersebut adalah tanah liat. Tanah liat dapat digunakan sebagai media khususnya dalam mengenalkan bentuk dasar tiga dimensi.
\end{abstract}

Kata Kunci: Tanah Liat, Media Pembelajaran, Bentuk Dasar Tiga Dimensi

\section{A. PENDAHULUAN}

Pendidikan anak usia dini merupakan upaya untuk menstimulasi, membimbing, mengasuh dan memberikan kegiatan pembelajaran yang mampu menghasilkan kemampuan dan keterampilan anak. Pendidikan anak usia dini merupakan suatu pendidikan yang dilakukan pada anak sejak lahir hingga usia delapan tahun. Pada usia ini kegiatan bermain merupakan sesuatu yang sangat penting dalam perkembangan kepribadiannya. Bermain bagi seorang anak tidak sekedar untuk mengisi waktu, tetapi media bagi anak untuk belajar. Setiap bentuk kegiatan bermain pada anak pra-sekolah mempunyai nilai positif terhadap semua aspek perkembangannya misalnya, perkembangan kognitif, motorik, bahasa, fisik, sosial-emosional, dan kemandirian dari seorang anak. Di dalam bermain sebaiknya anak menggunakan alat permainan yang edukatif, karena berfungsi untuk memfasilitasi anak-anak mengembangkan hubungan yang harmonis, melatih anak untuk berkomunikasi, juga melatih anak untuk memiliki keterampilan bersosalisasi, baik antar teman sebaya maupun lingkungan sekitarnya. Ketika anak bermain, anak memiliki nilai kesempatan untuk mengekspresikan sesuatu yang ia rasakan dan pikirkan. Dengan bermain, anak sebenarnya sedang mendapatkan kepuasan dalam bermain, yang berarti mengembangkan dirinya sendiri.

Alat permainan yang edukatif juga dapat digunakan sebagai media dalam proses pembelajaran, sehingga dapat mempertinggi proses belajar dalam pembelajaran yang pada gilirannya diharapkan dapat mempertinggi hasil belajar yang dicapainya. Berbagai penelitian yang dilakukan terhadap penggunaan media dalam pembelajaran sampai pada kesimpulan, bahwa proses dan hasil belajar pada

1 Mahasiswa Program Studi Pendidikan Dasar Sekolah Pascasarjana UPI 
anak menunjukkan perbedaan yang signifikan antara pembelajaran tanpa media dengan pembelajaran menggunakan media yang menarik. Oleh karena itu penggunaan media pembelajaran sangat dianjurkan untuk mempertinggi kualitas pembelajaran.

Berdasarkan latar belakang masalah di atas, secara umum, penyusunan makalah ini bertujuan untuk memperoleh pemahaman tentang pengembangan media pembelajaran bagi anak usia dini. Adapun secara khusus penyusunan makalah ini bertujuan untuk: (1) mengetahui karakteristik media yang cocok digunakan pada proses pembelajaran anak usia dini dan (2) mengetahui kelebihan penggunaan tanah liat sebagai media pembelajaran anak usia dini.

\section{B. PEMBAHASAN}

\section{Pengertian Media Pembelajaran}

Kata media berasal dari bahasa Latin yaitu medius yang artinya tengah, perantara atau pengantar. Kata media, merupakan bentuk jamak dari kata "medium", yang secara etimologi berarti perantara atau pengantar. Menurut Luhan dalam Basuki (1992) media adalah semua saluran pesan yang dapat digunakan sebagai sarana komunikasi dari seseorang kepada orang lain yang tidak ada dihadapannya. Dari pendapat ini dapat disimpulkan bahwa media adalah segala alat bantu yang dapat digunakan sebagai perantara untuk menyampaikan bahan yang telah direncanakan oleh penyaji kepada siswa sehingga apa yang menjadi tujuan pembelajaran dapat tercapai.

Selanjutnya, media pembelajaran merupakan segala sesuatu yang dapat digunakan untuk menyalurkan pesan, dapat merangsang pikiran, perasaan, dan kemauan peserta didik sehingga dapat mendorong terciptanya proses belajar pada diri peserta didik. Media dapat digunakan dalam proses pembelajaran dengan cara dua arah yaitu sebagai alat bantu mengajar atau yang sering disebut dependent media contoh gambar, foto atau transparansi untuk menerangkan sesuatu, dan sebagai media belajar yang dapat digunakan sendiri oleh siswa yang sering disebut independent media contoh radio, TV, video, film.

\section{Fungsi Media Pembelajaran}

Levie \& Lents (1982) mengemukakan empat fungsi media pembelajaran, khususnya media visual, yaitu:

a. Fungsi Atensi

Fungsi atensi media visual merupakan inti, yaitu menarik dan mengarahkan perhatian siswa untuk berkonsentrasi kepada isi pelajaran yang berkaitan dengan makna visual yang ditampilkan atau menyertai teks materi pelajaran. Seringkali pada awal pelajaran siswa tidak tertarik dengan materi pelajaran atau mata pelajaran itu merupakan salah satu pelajaran yang tidak disenangi oleh mereka sehingga mereka tidak memperhatikan. Media gambar khususnya gambar yang diproyeksikan melalui overhead projector dapat menenangkan dan mengarahkan perhatian mereka kepada pelajaran yang akan mereka terima. Dengan demikian, kemungkinan untuk memperoleh dan mengingat isi pelajaran semakin besar. 


\section{b. Fungsi Afektif}

Media visual dapat terlihat dari tingkat kenikmatan siswa ketika belajar (atau membaca) teks yang bergambar. Gambar atau lambang visual dapat menggugah emosi dan sikap siswa, misalnya informasi yang menyangkut masalah social atau ras.

c. Fungsi Kognitif

Fungsi kognitif media visual terlihat dari temuan-temuan penelitian yang mengungkapkan bahwa lambang visual atau gambar memperlancar pencapaiaan tujuan untuk memahami dan mengingat informasi atau pesan yang terkandung dalam gambar.

d. Fungsi Kompensatoris

Fungsi kompensatoris media pembelajaran terlihat dari hasil penelitian bahwa media visual yang memberikan konteks untuk memahami teks membantu siswa yang lemah dalam membaca untuk mengorganisasikan informasi dalam teks dan mengingatnya kembali. Dengan kata lain, media pembelajaran berfungsi untuk mengakomodasikan siswa yang lemah dan lambat menerima dan memahami isi pelajaran yang disajikan dengan teks atau disajikan secara verbal.

Media pembelajaran, menurut Kemp \& Dayton (1985:28), dapat memenuhi tiga fungsi utama apabila media itu digunakan untuk perorangan, kelompok, atau kelompok pendengar yang besar jumlahnya, yaitu :

a. Memotivasi minat atau tindakan,

b. Menyajikan informasi,

c. Memberi instruksi.

Untuk memenuhi fungsi motivasi, media pembelajaran dapat direalisasikan dengan teknik drama atau hiburan. Hasil yang diharapkan adalah melahirkan minat dan merangsang para siswa atau pendengar untuk bertindak (turut memikul tanggung jawab, melayani secara sukarela, atau memberikan subangan material). Pencapaian tujuan ini akan memperngaruhi sikap, nilai, dan emosi.

Untuk tujuan informasi, media pembelajaran dapat digunakan dalam rangka penyajian informasi dihadapan sekelompok siswa. Isi dan bentuk penyajian bersifat amat umum, berfungsi sebagai pengantar, ringkasan laporan, atau pengetahuan latar belakang. Penyajian dapat pula berbentuk hiburan, drama, atau teknik motivasi. Ketika mendengar atau menonton bahan informasi, para siswa bersifat pasif. Partisipasi yang diharapkan dari siswa hanya terbatas pada persetujuan atau ketidaksetujuan mereka secara mental, atau terbatas pada perasaan tidak/kurang senang, netral, atau senang.

Media berfungsi untuk tujuan instruksi di mana informasi yang terdapat dalam media itu harus melibatkan siswa baik dalam benak atau mental maupun dalam bentuk aktivitas yang nyata sehingga pembelajaran dapat terjadi. Materi harus dirancang secara lebih sistematis dan psikologis dilihat dari segi prinsipprinsip belajar agar dapat menyiapkan instruksi yang efektif. Di samping menyenangkan, media pembelajaran harus dapat memberikan pengalaman yang menyenangkan dan memenuhi kebutuhan perorang siswa. 


\section{Manfaat Media Pembelajaran}

Secara umum, manfaat media dalam proses pembelajaran adalah memperlancar interaksi antara guru dengan siswa sehingga pembelajaran akan lebih efektif dan efisien. Tetapi secara lebih khusus ada beberapa manfaat media yang lebih rinci menurut Kemp dan Dayton (1985) yaitu:

a. Penyampaian materi pelajaran dapat diseragamkan.

b. Proses pembelajaran menjadi lebih jelas dan menarik.

c. Proses pembelajaran menjadi lebih interaktif.

d. Efisiensi dalam waktu dan tenaga.

e. Meningkatkan kualitas hasil belajar siswa.

f. Media memungkinkan proses belajar dapat dilakukan dimana saja dan kapan saja.

g. Media dapat menumbuhkan sikap positif siswa terhadap materi dan proses belajar.

h. Merubah peran guru ke arah yang lebih positif dan produktif.

\section{Jenis - Jenis Media Pembelajaran}

Anderson (1976) mengelompokkan media menjadi 10 golongan, diantaranya sebagai berikut:

\begin{tabular}{|l|l|l|}
\hline \multicolumn{1}{|c|}{ No } & Golongan Media & \multicolumn{1}{c|}{ Contoh dalam Pembelajaran } \\
\hline I & Audio & Kaset audio, siaran radio, CD, telepon \\
\hline II & Cetak & Buku pelajaran, modul, brosur, leaflet, gambar \\
\hline III & Audio-cetak & Kaset audio yang dilengkapi bahan tertulis \\
\hline IV & Proyeksi visual diam & Overhead transparansi (OHT), Film bingkai (slide) \\
\hline V & $\begin{array}{l}\text { Proyeksi Audio } \\
\text { visual diam }\end{array}$ & Film bingkai (slide) bersuara \\
\hline VI & Visual gerak & Film bisu \\
\hline VII & & $\begin{array}{l}\text { Audio Visual gerak, film gerak bersuara, video/VCD, } \\
\text { televise }\end{array}$ \\
\hline VIII & Obyek fisik dan & Benda nyata, model, specimen \\
\hline IX & $\begin{array}{l}\text { Manusia } \\
\text { lingkungan }\end{array}$ & $\begin{array}{l}\text { CAI Pustakawan, Laboran } \\
\text { (Pembelajaran berbasis komputer).[7] }\end{array}$ \\
\hline X & Komputer & \multicolumn{1}{c}{ bBI } \\
\hline
\end{tabular}

\section{Karakteristik Media yang Cocok Digunakan pada Proses Pembelajaran Anak Usia Dini}

Saat menggunakan media yang cocok dalam pembelajaran, anak diberi kesempatan untuk bereksperimen dan bereksplorasi secara luas terhadap media tersebut. Dalam hal ini media pembelajaran berguna untuk :

a. Menimbulkan kegairahan belajar

b. Memungkinkan interaksi yang lebih langsung antara anak didik dengan lingkungan dan kenyataan. 
c. Memungkinkan anak didik belajar sendiri-sendiri menurut kemampuan dan minat.

\section{Penggunaan Tanah Liat Sebagai Media Pembelajaran Pengenalan Bentuk Dasar Tiga Dimensi Bagi Pendidikan Anak Usia Dini}

Salah satu contoh media yang cukup interaktif, kreatif, dan tentu saja mengandung unsur edukatif bagi anak usia dini ialah dengan menggunakan tanah liat sebagai medianya.

Tanah liat dihasilkan oleh alam, yang bersal dari pelapukan kerak bumi yang sebagian besar tersusun oleh batuan feldspatik, terdiri dari batuan granit dan batuan beku. Kerak bumi terdiri dari unsur unsur seperti silikon, oksigen, dan aluminium. Aktivitas panas bumi membuat pelapukan batuan silika oleh asam karbonat. kemudian membentuk terjadinya tanah liat.

Tanah Liat atau tanah lempung memiliki ciri-ciri sebagai berikut.

a. Tanahnya sulit menyerap air sehingga tidak cocok untuk dijadikan lahan pertanian.

b. Tekstur tanahnya cenderung lengket bila dalam keadaan basah dan kuat menyatu antara butiran tanah yang satu dengan lainnya.

c. Dalam keadaan kering, butiran tanahnya terpecah-pecah secara halus.

d. Merupakan bahan baku pembuatan tembikar dan kerajinan tangan lainnya yang dalam pembuatannya harus dibakar dengan suhu di atas 10000C.

Fungsi tanah liat sebagai media pembelajaran:

a. Membangun daya imajinasi, koordinasi dan keseimbangan motorik anak.

b. Melatih kreatifitas pada anak usia dini.

c. Membuat karya seni merupakan keriangan dengan proses yang menarik.

d. Melatih ketekunan, kerapihan, dan kesabaran

\section{Kelebihan Penggunaan Tanah Liat Sebagai Media Pembelajaran Anak Usia Dini}

Menurut Sumanto (2005: 191) tujuan dimanfaatkannya lingkungan alam dan budaya dalam pembelajaran seni rupa adalah:

a. Agar pembelajaran bisa lebih efektif, dengan lingkungan yang sudah dikenal anak maka anak dapat menerima dan menguasai dengan baik.

b. Agar pelajaran jadi relevan dengan kebutuhan siswa sesuai dengan minat dan perkembangannya.

c. Agar lebih efisien murah dan terjangkau yakni dengan menggunakan bahan alam, seperti tanah liat.

d. Karena pembelajaran yang disukai anak adalah melalui bermain maka metode bermain dengan tanah liat sangat tepat untuk langkah awal pembentukan kreativitas karena diawali dengan proses melemaskan tanah liat dengan meremas, merasakan, menggulung, memipihkan, dll. 


\section{PENUTUP}

Media berasal dari bahasa Latin yang mempunyai makna perantara, pengantar, antar. Makna tersebut dapat dimengerti sebagai alat komunikasi yang digunakan untuk membawa suatu informasi yang berasal dari sesuatu sumber pesan kepada penerima pesan. Dari berbagai pendapat tentang pengertian media, maka dapat ditarik kesimpulan bahwa pengertian media dalam pembelajaran adalah segala bentuk alat komunikatif yang dapat digunakan untuk menyampaikan pesan/informasi dari sumber kepada anak didik yang bertujuan agar dapat merangsang pikiran, perasaan, minat dan perhatian anak didik untuk mengikuti kegiatan pembelajaran.

Media memiliki peran dalam proses belajar-mengajar, yaitu:

1. Memperjelas penyajian pesan dan mengurangi verbalitas.

2. Memperdalam pemahaman anak didik terhadap materi pelajaran;

3. Memperagakan pengertian yang abstrak kepada pengertian yang koonkret dan jelas;

4. Mengatasi keterbatasan ruang, waktu dan daya indera manusia;

5. Penggunaan media pembelajaran yang tepat akan mengurangi sikap pasif anak didik.

6. Mengatasi sifat unik pada setiap anak didik yang diakibatkan oleh lingkungan yang berbeda;

7. Media mampu memberikan variasi dalam belajar-mengajar.

\section{DAFTAR PUSTAKA}

Anderson, Ronald H. (1993). Pemilihan dan Pengembangan Media untuk Pembelajaran. Jakarta: Universitas Terbuka dan PT Raja Grafindo Persada

Kustandi, Cecep dan Bambang Sutjipto. (2011). Media Pembelajaran Manual dan Digital. Bogor: Ghalia Indonesia.

Sumantri, Mulyani dan Johar Permana. (1998). Strategi Belajar Mengajar. Jakarta: Depdikbud.

Susilana, Rudi dan Cepi Riyana. (2007). Media Pembelajaran Hakikat, Pengembangan, Pemanfaatan, dan Penilaian. Bandung: CV Wacana Prima. 